\title{
Implementasi Hysterisis Current Control Pulse Witdh Modulation (HCCPWM) untuk Inverter 3 Fasa
}

\author{
Tri Yogi Putra1 ${ }^{1}$ Muldi Yuhendri ${ }^{2}$ \\ 1,2 Jurusan Teknik Elektro, Fakultas Teknik, Universitas Negeri Padang \\ Jl. Prof. Dr. Hamka, Air Tawar Padang, 35132, Indonesia \\ Yogiputra148@ymail.com¹, muldiy@ft.unp.ac.id ${ }^{2}$
}

\begin{abstract}
Based on the source used, there are several types of converters, one of which is a voltage source converter (VSC). In this study, using a converter that can work as an inverter. In industry, an inverter is useful for supplying the AC voltage source from industrial plants with DC sources, by varying the voltage and output frequency of the inverter. The method used is the HCCPWM generation method or Hysterisis Current Control Pulse Witdh Modulation. This method was chosen because it has several advantages which are good stability, very fast transient response and good accuracy. To activate HCCPWM, a 3 phase reference current signal is first made in the Matlab Simulink, this reference current is then compared with the actual current from the current sensor, then the error is controlled with the hysteresis band. In Arduino mega2560, the pulses generated by HCCPWM in the Matlab Simulink are converted into a duty cycle. The modulated pulse generated by the Arduino PWM pin will be increased using a gate drive circuit, so that the voltage is obtained according to the voltage required by the Mosfet to activate the switch. The results of the tests that have been done show that the voltage source converter (VSC) designed in this study has worked well as intended. This can be seen from the actual current from the current sensor which has been compared with the reference voltage using the HCCPWM method which is included in the Simulink Matlab program.
\end{abstract}

Keywords - Voltage Source Converter, HCCPWM, arduino mega2560, matlab simulink

Abstrak-Bedasarkan sumber yang di gunakan, ada beberapa jenis konverter, salah satu yang digunakan adalah konverter sumber tegangan atau voltage source converter (VSC). Pada penelitian ini menggunakan konveter yang dapat bekera sebagai inverter. Pada industri, sebuah inverter berguna untuk pemasok sumber tegangan AC dari pembangkit industri yang bersumber DC, dengan cara memvariasikan tegangan dan frekuensi keluaran dari inverter tersebut. Metode yang di gunakan adalah metode pembangkitan HCCPWM atau Hysterisis Current Control Pulse Witdh Modulation. Metode ini dipilih karena memiliki beberapa keunggulan yang mana memiliki stabilitas bagus, respons transien yang sangat cepat dan akurasi yang baik. Untuk mengaktifkan HCCPWM, terlebih dahulu dilakukan pembuatan sinyal arus 3 fasa referensi dalam Simulink matlab, arus referensi ini kemudian di bandingkan dengan arus aktual dari sensor arus, kemudian error nya di kendalikan dengan hysteresis band. Pada arduino mega2560, pulsa yang dihasilkan HCCPWM dalam Simulink matlab di konversikan menjadi duty cycle. Pulsa modulasi yang di hasilkan pin pwm arduino akan dinaikan menggunakan rangkaian gate drive, sehingga di peroleh tegangan yang sesuai dengan tegangan yang di butuhkan oleh mosfet untuk mengaktifkan saklar nya. Hasil pengujian yang sudah dilakukan menunjukan bahwa voltage source converter (VSC) yang dirancang dalam penelitian ini telah bekerja dengan baik sesuai dengan tujuan. Hal ini dilihat dari arus aktual dari sensor arus yang telah dibandingkan dengan tegangan referensi menggunakan metode HCCPWM yang dimasukkan dalam program Simulink matlab.

Kata kunci- Voltage Source Converter, HCCPWM, arduino mega2560, simulink matlab.

\section{Pendahuluan}

Di dunia industri sekarang ini banyak diterapkan pengendalian kecepatan motor untuk berbagai keperluan tenaga penggerak. pengendalian kecepatan motor ini umumnya menggunakan konverter daya yang dapat mengendalikan tegangan, arus ataupun frekuensi motor. secara umum, ada 2 jenis tegangan yang dapat digunakan untuk berbagai keperluan, yaitu tegangan bolak-balik yang disebut juga dengan alternating current (ac) dan tegangan searah yang disebut juga dengan direct current (dc)[1]. Dalam penelitian ini dirancang konverter daya yang dapat digunakan sebagai konverter daya pada kendali motor listrik ac 3 fasa. Berdasarkan sumber yang digunakan, konverter yang dapat dikelompokan atas dua jenis, Voltage Source Konverter (VSC) dan Current Source Konverter (CSC)[2]. Perbedaannya adalah Voltage Source Konverter (VSC) menggunakan filter kapasitor sedangkan Current Source Konverter (CSC) menggunakan filter induktor. Dalam tugas akhir ini dipilih konverter jenis sumber tegangan, karena memiliki rugi daya yang lebih rendah dibandingkan sumber arus. Modulasi switch konverter dapat dilakukan dengan beberapa metode switching dengan frekuensi tertentu. Switching sendiri merupakan proses konduksi switch dalam jangka waktu dari kondisi ON sampai kondisi OFF. Waktu ON dan OFF 
switch ini akan menentukan besaran tegangan keluaran konverter. Oleh sebab itu untuk mengatur tegangan keluaran konverter, maka waktu ON dan OFF switch konverter harus diatur. Salah satu teknik pengaturan waktu ON dan OFF switch konverter ini adalah teknik pelebaran pulsa modulasi atau Pulse Width Modulation (PWM)[3]. Untuk mengubah kecil besarnya Pulse Width Modulation (PWM) dapat digunakan dengan komponen switching berupa Mosfet, serta Penggunaan rangkaian gate drive yang berguna untuk menguatkan sinyal serta sebagai pengaman antara rangkaian kontrol dan rangkaian utamanya[4]. Metode PWM yang digunakan adalah dengan Hysterisis Current Control Width Modulation (HCCPWM), yang bekerja bedasarkan hysteresis band arus keluaran inverter. Metode Hysterisis Current Control Pulse Width Modulation (HCCPWM) ini memiliki beberapa keunggulan dari pada metode Pulse Width Modulation (PWM) yang lainnya untuk implementasi konverter pada kendali motor, keunggulannya seperti memiliki stabilitas bagus, respons transien yang sangat cepat dan akurasi yang baik, frekuensi switching konstan dan menghilangkan ketergantungan antar fase, dinamika yang sangat baik dan sangat mudah di implementasikan untuk kendali vektor[5]. Beberapa mikrokontroler yang telah digunakan untuk konverter antara lain seperti miktokontroller Atmega[6] dan Arduino[7]-[8]. Metode HCCPWM ini akan diimplementasikan dengan hardware arduino mega 2560 yang diprogram dengan software Simulink Matlab. Arduino ini dipilih karena harganya murah dan mudah diimplementasikan.

\section{Metode}

Penelitian ini dilakukan dalam bentuk eksperimen yang dimulai dengan perancangan, pembuatan dan pengujian menggunakan Simulink matlab.

\section{Voltage Source Converter (VSC)}

VSC adalah konverter yang menggunakan sumber tegangan dengan penyimpan energi berupa kapasitor. Berdasarkan semikonduktor yang digunakan, VSC dapat beroperasi dalam beberapa model. Konverter yang menggunakan semikonduktor bidirectional dapat beroperasi dalam dua model, yaitu model penyearah (rectifier) dan model inverter. Dalam model penyearah, konverter akan mengubah tegangan $\mathrm{AC}$ menjadi tegangan DC. Dalam model inverter, konverter akan mengubah tegangan DC menjadi tegangan AC. Hal ini dapat dilakukan dengan menggunakan semikonduktor daya dua arah (bidirectional), seperti MOSFET dan IGBT, sehingga arus dapat mengalir dua arah.

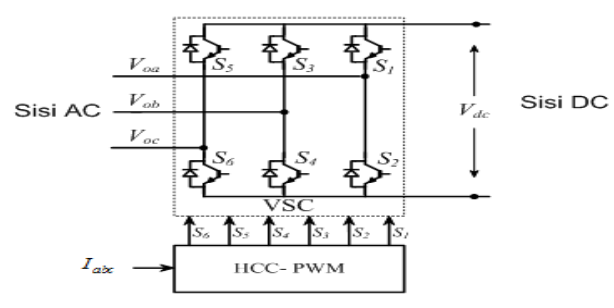

Gambar 1. Menunjukan struktrur [VSC]

[9]

\section{Arduino Mega 2560}

Arduino merupakan perangkat Mikrokontroler yang bersifat open source, yang mana menggunakan IC mikrokontroler ATMega sebagai komponen utamanya. Pemograman pada arduino menggunakan bahasa pemograman tersendiri. Arduino sangat berperan penting dalam pengendalian berbagai macam motor dan rangkaian elektronik, maupun untuk pengendalian berbagai macam perangkat. Pada arduino memiliki berbagai macam seri, salah satunya adalah Arduino Mega 2560. Pada gambar 2 dapat dilihat bentuk Arduino Mega 2560.[10]

Arduino Mega 2560 Merupakan sebuah perangkat mikrokontroler yang mempunyai 54 input atau output digital yang mana 16 pin digunakan sebagai PWM keluaran, 16 masukan analog, dan di dalamnya terdapat 16 MHZ osilator kristal, power, USB koneksi, tombol reset dan ICSP.[11]

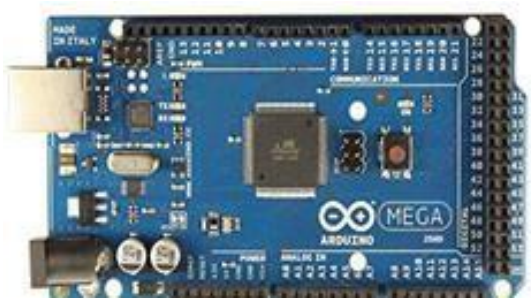

Gambar 2. Board Arduino Mega2560

\section{Hysterisis Current Control PWM}

Untuk Mengatur $\mathrm{T}_{\text {on }}$ dan $\mathrm{T}_{\text {off }} \mathrm{PWM}$ dapat dilakukan dengan beberapa metode, salah satunya dengan metode Hysterisis Current Control. Dalam metode ini pulsa output PWM diatur berdasarkan perubahan arus referensi dengan arus aktual menggunakan hysterisis band[12]. Hysterisis Current Control pada dasarnya kuat pada penyimpangan parameter beban, sehingga efek transiennya sangat cepat dan mudah digunakan. HCCPWM bekerja dengan referensi arus, dimana arus referensi ini (iref) dibandingkan dengan arus terukur pada keluaran converter dan errornya dikendalikan dengan hysteresis band, yang akan menentukan lebar pulsa modulasi dari switch converter. 


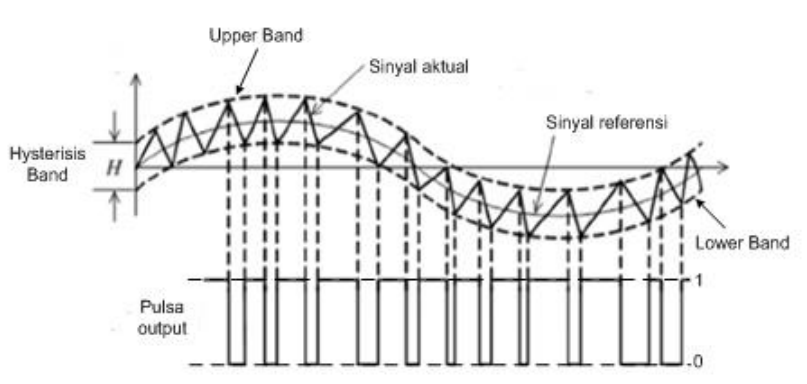

Gambar 3. HCCPWM

\section{Sensor Arus ACS712}

Sensor ACS712 ini mempunyai tingkat pengukuran arus dari rentang mili hingga 5 ampere, yang mana telah dilengkapi dengan penguat sehingga memudahkan pengguna untuk mengukur arus.[13]

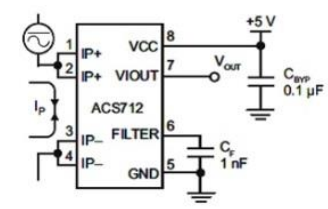

Gambar 4. Sensor Arus ACS712

\section{Mosfet}

Sebuah komponen yang memiliki kecepatan switching yang sangat tinggi bahkan kecepatan switching nya memiliki orde nanodetik dan dikendalikan oleh tegangan serta memerlukan arus masukan yang kecil merupakan beberapa ciri-ciri dari MOSFET[14]. MOSFET umumnya memiliki 3 kaki, yaitu Gate (G), Drain (D), dan Source (S). Dari segi bahan semikonduktor pembuatnya, MOSFET terbagi atas 2 bagian yaitu MOSFET N-type dan MOSFET P-type. Bentuk schematic dari MOSFET dapat dilihat pada gambar dibawah ini.

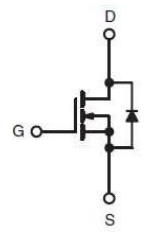

Gambar 5. Mosfet IRFP460

\section{Gate Drive}

Merupakan sebuah rangkaian yang dapat menghubungkan tegangan daya tinggi dengan tegangan kontrol pengendalian[15]. Fungsi dari gate drive tidak hanya untuk isolasi rangkaian daya dan kontrol, tetapi pada beberapa jenis gate drive untuk Mosfet dan IGBT juga sebagai rangkaian penguat sinyal switching, fungsinya untuk memenuhi syarat aktif switching dari Mosfet atau IGBT tersebut.



Gambar 6. Diagram Gate Drive Pada Sistem Elektonika Daya

\section{Simulink Matlab}

Pada Simuink Matlab telah menyediakan komponen yang berfungsi untuk mempermudah dalam mendesain tampilan program. Sehingga dalam Pembuatan program tidak diperlukan lagi dalam penulisan kode untuk membuat tampilannya. Tampilan di dalam Simulink Matlab dapat diatur dengan cara mengambil tools yang akan dipakai pada form yang sudah tersedia[16].

Simulink Merupakan sebuah modul dari matlab yang Bisa digunakan untuk mensimulasikan sistem dinamik dengan cara grafis berbentuk diagram blok, sistem dinamik dapat dimodelkan dengan diagram blok, panah sinyal, summing junction, blok gain, source dan sink [17].

\section{Blok Diagram}

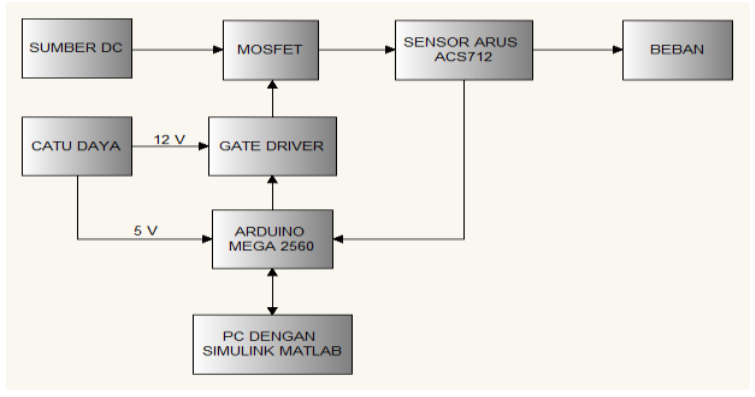

Gambar 7. Blok Diagram

Voltage Source Konverter (VSC) yang dirancang dalam tugas akhir ini adalah dengan teknik modulasi HCCPWM. Untuk mengaktifkan HCCPWM, terlebih dahulu dilakukan pembuatan sinyal arus 3 fasa referensi dalam Simulink Matlab. Nilai dan frekuensi arus referensi ditetapkan untuk menentukan besaran dan frekuensi arus yang akan dilewatkan konverter ke beban. Arus referensi ini kemudian dibandingkan dengan arus aktual dari sensor arus, kemudian errornya dikendalikan dengan hysteresis band. Blok hysteresis band ini, akan menghasilkan pulsa PWM untuk modulasi sakelar aktif konverter. Bandwidth hysteresis ditetapkan untuk menentukan batas atas dan batas bawah error arus yang akan mengalihkan posisi switching dari OFF ke ON atau sebaliknya. Pulsa hysteresis band akan ON jika pergerakan error arus berada dari batas bawah band menuju batas atas. Sebaliknya, pulsa hysteresis band akan beralih ke posisi OFF jika error arus mencapai batas atas band dan bergerak sampai menyentuh batas bawah band.

Pada arduino, pulsa modulasi yang dihasilkan HCCPWM dalam Simulink Matlab dikonversikan menjadi duty cycle sesuai dengan frekuensi switching yang diset pada arduino tersebut. Dalam arduino, pulsa keluaran HCCPWM dikonversikan ke dutycycle dengan rentang nilai 
0-255. Dengan cara ini, maka pin arduino yang telah dialamatkan dalam program Simulink matlab akan menghasilkan pulsa modulasi sesuai dengan pulsa modulasi HCCPWM.

Pulsa modulasi yang dihasilkan pin PWM arduino akan dinaikan dengan menggunakan rangkaian gate driver, sehingga diperoleh tegangan yang sesuai dengan tegangan yang dibutuhkan oleh gate IGBT untuk mengaktif switchnya. Ketika pin gate IGBT mendapat sinyal tegangan dari rangkaian driver, maka switch IGBT akan konduksi sesuai dengan kondisi pulsa PWM pada rangkaian driver gate. Dengan cara seperti ini, maka VSC akan mengalirkan arus sesuai dengan arus referensi yang dibangkitkan dalam Simulink Matlab.

Perancangan hardware merupakan bagian yang sangat penting dalam pembuatan Voltage Source Converter ini , karena merupakan suatu tahapan dalam pembuatan alat. Agar saat proses pengerjaan tingkat kesalahan dapat dikurangi dan mempermudah dalam proses pembuatan alat tersebut. Dengan adanya perancangan hardware ini barulah kinerja sistem dapat diuji secara nyata.

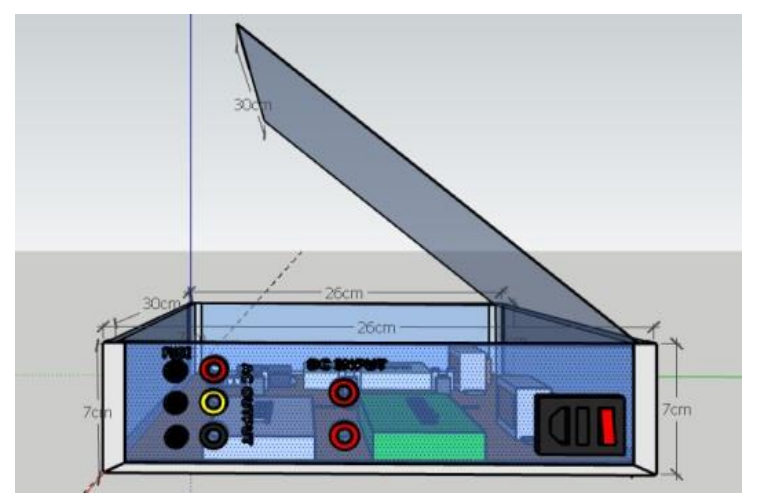

Gambar 7. Rancangan Hardware

\section{HASIL DAN PEMbahaSAN}

Alat Voltage Source Konverter yang telah dibuat di ujikan ke pada beban resistor , yang mana sumber diambil dari sumber DC yang di hubungkan dengan rangkaian alat. Rangkaian alat terdiri dari, rangkaian catu daya, rangkaian gate drive, rangkaian mosfet, sensor arus 3 buah, dan arduino mega 2560, yang mana nantinya akan di program melalui Simulink matlab. Setelah selesai membuat program Arduino menggunakan Simulink Matlab, selanjutnya dilakukan pengujian alat. Untuk melihat grafik keluaran inverter dan pwm Arduino digunakan osiloskop digital, sedangkan untuk melihat grafik arus referensi dan arus actual digunakan blok scope yang ada dalam Simulink Matlab. Gambar 8. menunjukan foto pengujian alat yang dilakukan.

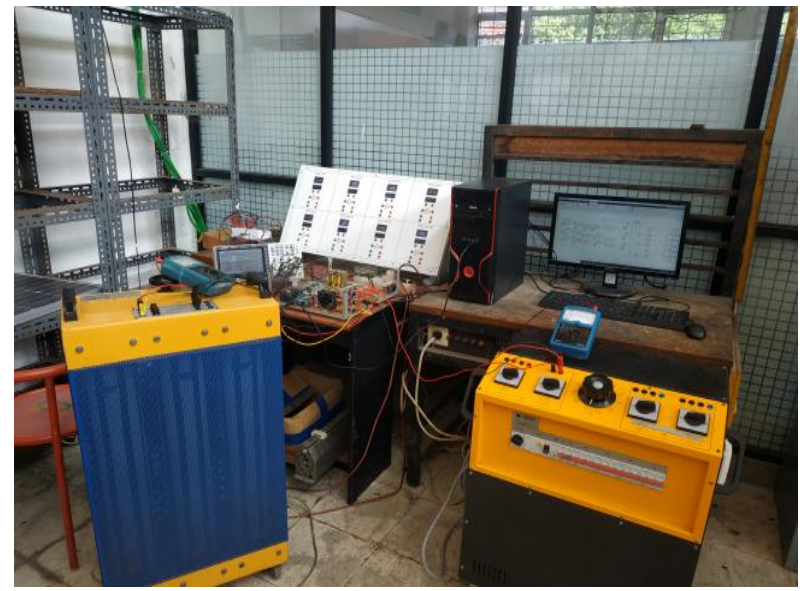

Gambar 8. Rangkaian Pengujian Alat

Pada gambar 8 rangkaian penguijian alat, dilihat bahwa rangkaian Voltage Source Konverter dibutuhkan komponen-komponen tambahan, seperti power pack, load resistor 3 fasa, osiloscope digital dan sebuah PC yang di gunakan untuk pemograman menggunakan Simulink matlab.

\section{Pengujian Software}

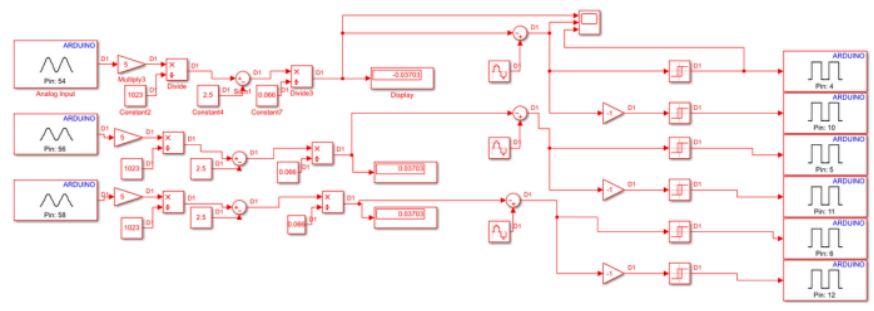

Gambar 9. Program Voltage Source konverter dalam Simulink Matlab

Dari gambar program di atas dilihat bahwa, terdapat 3 buah analog input sebagai sensor arus, dan 6 buah digital output sebagai keluaran 6 buah pin di arduino mega 2560 untuk mengeluarkan sinyal PWM, yang mana nantinya akan di gabungkan dengan blok gelombang blok sinus sebanyak 3 buah.

\section{Pengujian Alat keseluruhan}

Pada Pengujian alat keseluruhan, yang di uji adalah keluaran arus referensi ditetapkan untuk menentukan besaran dan frekuensi arus yang akan dilewatkan konverter ke beban. Arus referensi ini kemudian dibandingkan dengan arus aktual dari sensor arus, kemudian errornya dikendalikan dengan hysteresis band. Blok hysteresis band.

Untuk gambar keluaran Hysterisis Band, dapat dilihat dari gambar 11-13. 


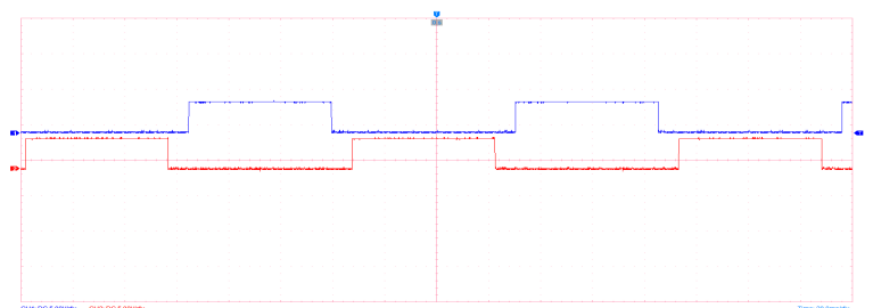

Gambar 11. Hysteresis Band Fasa 1

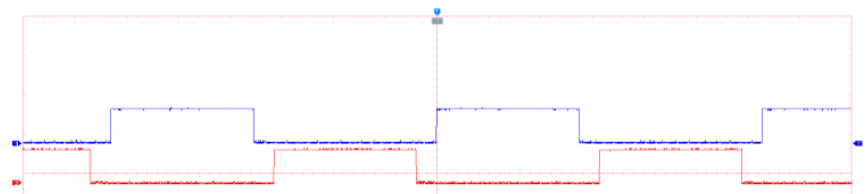

Gambar 12. Hysteresis Band Fasa 2

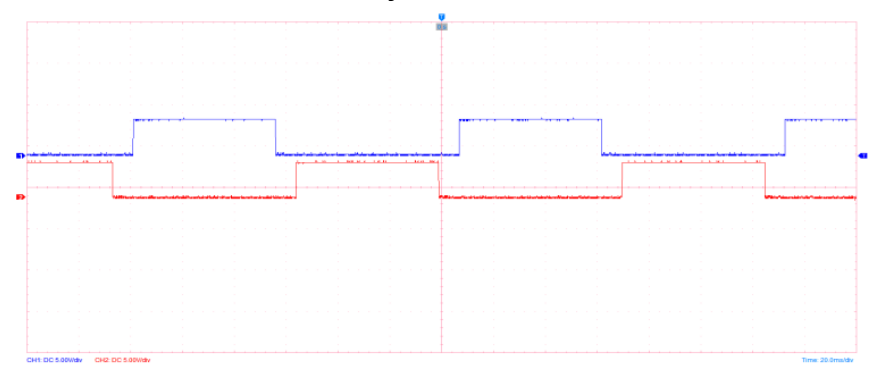

Gambar 13. Hysteresis Band Fasa 3

Bedasarkan pengujian Hysteresis Band Fasa 1,2 dan 3 pada gambar di atas dilihat bahwa, gambar keluaran Hysteresis Band Fasa yang di uji sudah sesuai, yang mana antara gelombang high dan low tidak saling hidup bersamaan.

\section{Pengujian Keluaran Inverter 3 fasa}

Pada pengujian inverter dilakukan untuk melihat gelombang keluaran inverter per fasa .

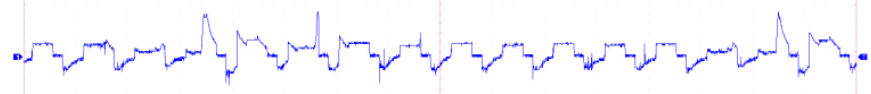

Gambar 14. Keluaran inverter Fasa RS

Pada gamabar 14 ini , dilihat gelombang keluaran inverter menggunakan osciloscop digital.

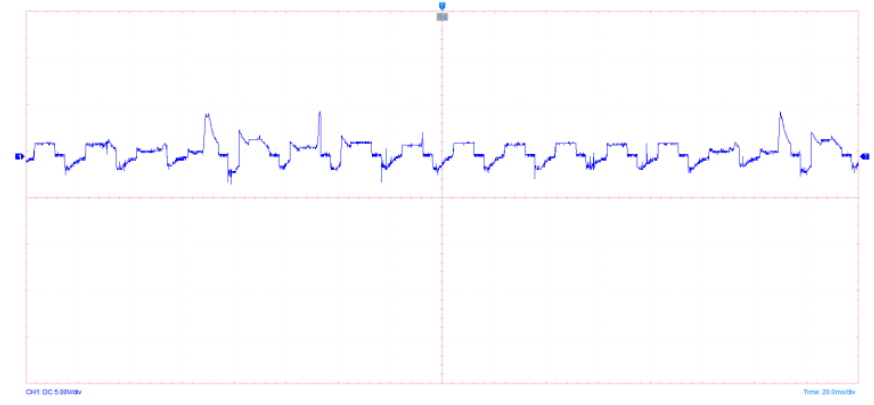

Gambar 15. Keluaran inverter Fasa ST

Pada gamabar 15 ini , dilihat gelombang keluaran inverter menggunakan osciloscop digital.

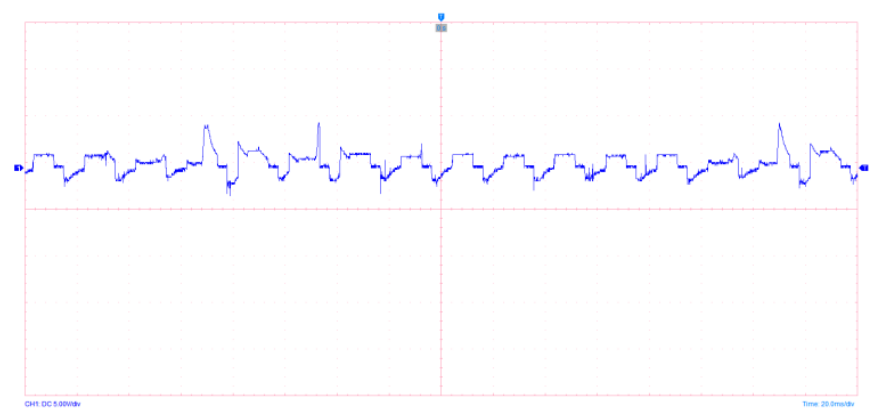

Gambar 16. Keluaran inverter Fasa ST

Pada gamabar 16 ini , dilihat gelombang keluaran inverter menggunakan osciloscop digital.

\section{Pengujian Arus Referensi Dan Arus Aktual}

Pada pengujian arus referensi dan aktual, arus aktual di uji dengan nilai $0,3,0,5$ dan 0,8 . Arus referensi dilihat dari keluaran sinyal gelombang dan arus aktual dari keluaran sensor arus. Yang mana nanti nya arus referensi dan arus aktual nantinya akan dibandingkan.
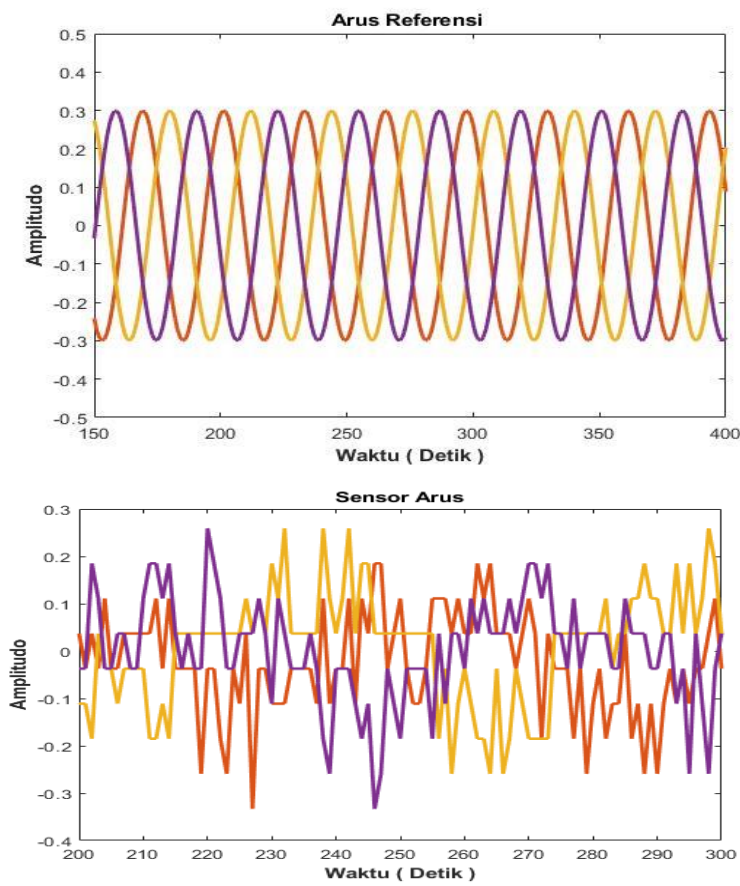
Gambar 17. Arus aktual dan arus referensi 0,3 Pada gambar 17, terlihat perbandingan antara arus referensi dengan arus aktual dari sensor arus.
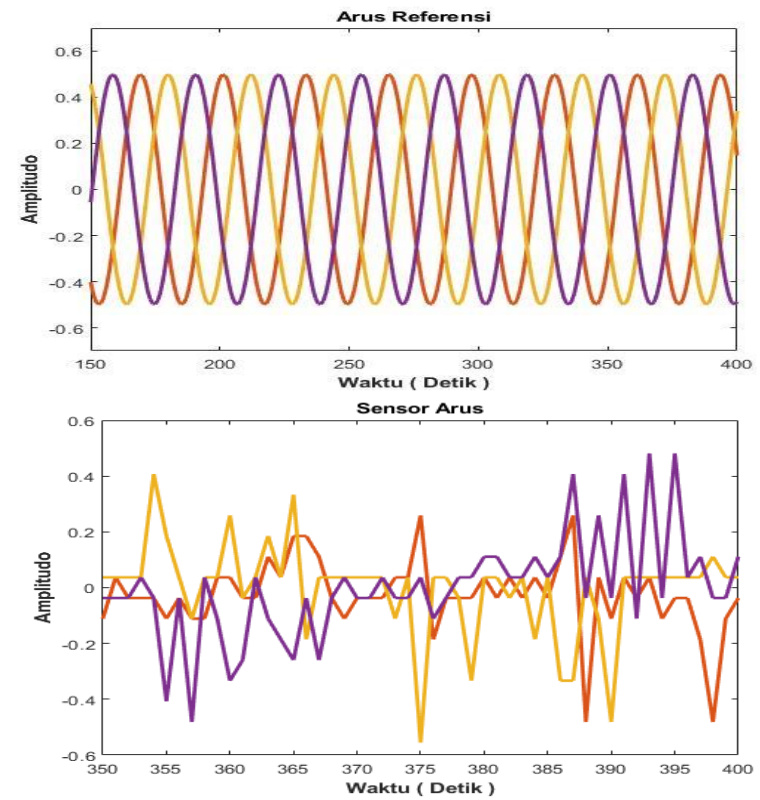

Gambar 18. Arus aktual dan arus referensi 0,5 Pada gambar 18, terlihat perbandingan antara arus referensi dengan arus aktual dari sensor arus.
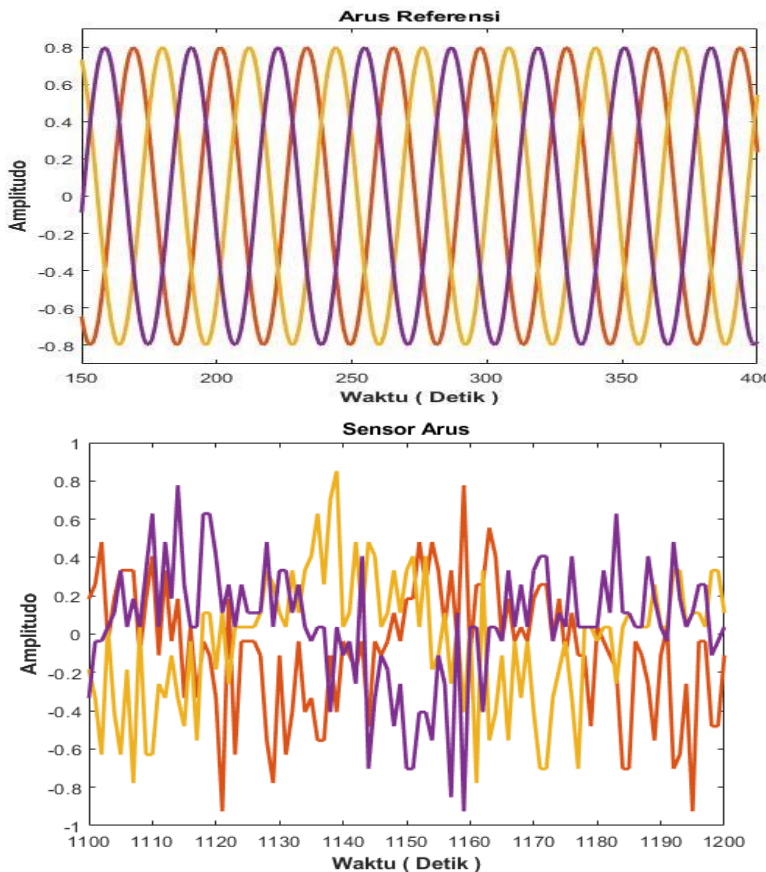

Gambar 19. Arus aktual dan arus referensi 0,8 Pada gambar 19, terlihat perbandingan antara arus referensi dengan arus aktual dari sensor arus.

\section{PENUTUP}

Penelitian ini mengusulkan sistem kendali voltage source converter berbasis Hysterisis Current Control Pulse Width Modulation (HCCPWM). Yang mana rancangan sistem yang diusulkan akan diimplementasikan dengan menggunakan arduino mega 2560 yang di program menggunakan Simulink Matlab. Dimana Dalam metode Hysterisis Current Control Pulse Width Modulation (HCCPWM) ini pulsa output dari PWM dapat diatur berdasarkan perubahan arus referensi dengan arus aktual menggunakan hysterisis band. Maka dari itu hasil pengujian menunjukan bahwa sistem kendali voltage source converter (VSC) telah bekerja dengan baik.

\section{REFERENSI}

[1] Aswardi, M. Yuhendri dan D. T. Yanto, Teknik Elektronika Daya, Indonesia : IRDH Book Publisher, 2020.

[2] Muhammad, Rashid. "Power Electronics Handboock". Florida: Butterworth Heineman, 2017

[3] Grant D, Seidner R, The Use Of Ratio Changing In Pulse-Width Modulted Inverter-an Integrated Circuit Approach, Power Conversion International, 7, 31-41, 1 Jan 1981.

[4] A. Aswaldi and M. Yuhendri, "Sitem Kendali Dan Monitoring Boost Converter Berbasis GUI (Graphical User Interface) Matlab Menggunakan Arduino", JTEIN, vol. 1, no 2, pp.266-272, 2020.

[5] Anurag Dwivedi, A.N Tiwari. " Analysis Of Three-Phase PWM Rectifiers Using Hysteresis Current Control Techniques". Electrical Engineering Department : Madan Mohan Malaviya University of technology, 2017.

[6] M. Cucuzzella, R. Lazzari, S. Trip, S. Rosti, C. Sandroni and A. Ferrara, "Sliding mode voltage control of boost converters in DC microgrids," Control Engineering Practice, vol. 73, pp. 161-170, April 2018.

[7] V. Viswanatha and R.V.S. Reddy, "Digital Control of Buck Converter Using Arduino Microcontroller For Low Power Applications", 2017 International Conference On Smart Technologies For Smart Nation (SmartTechCon), pp. 439-443,17-19 Aug 2017

[8] Enang.Edovidata,Hafelzan dan Aswardi."Perancangan Sistem Pengisian Accumulator Motor Listrik dengan Sumber Listri Solar Cell Berbasis Mikrokontroler". JTEV (Jurnal Teknik Elektro Dan Vokasional). (hal $57-$ 68). Padang : Teknik Elektro FT Universitas Negeri Padang.

[9] Mohan, Undeland, Robins. (1998). "Power Electronics, Converter, Applications and Desains". John Wiley \& Sons, Inc,

[10] F. Hidayat And K. Krismadinata, "Rancang Bangun Vvvf Inverter 3 Fasa Untuk Operasi Motor Induksi Tiga Fasa Dengan Antarmuka Komputer," Invotek J. Inov. Vokasional Dan Teknol., Vol. 19, No. 2, Pp. 47- 56, 2019.

[11] I. Oktariawan, "Pembuatan Sistem Otomasi Dispenser Menggunakan Mikrokontroler Arduino Mega 2560," J. 
Ilm. Tek. Mesin, Vol. 1, No. 2, 2013.

[12] A.D. Hikmah, 2018. Perancangan Sistem Kendali Daya Maksimum Pembangkit Listrik Tenaga Angin Menggunakan Boost Konverter Berbasis Optimum Torque Control. Tugas akhir, Padang:Unp

[13] H. Husnawati, R. Passarella, S. Sutarno, And R. Rendyansyah, "Perancangan Dan Simulasi Energi Meter Digital Satu Phasa Menggunakan Sensor Arus Acs712," J. Nas. Tek. Elektro Dan Teknol. Inf., Vol. 2, No. 4, Pp. 307-315, 2013.

[14] M. I. Dzakwan, I. Setiawan, A. Warsito, And T. Andromeda, "Perancangan Konverter Arus Searah Tipe Penurun Tegangan Dengan Mosfet Sinkron Dan Tanpa Mosfet Sinkron," Transient J. Ilm. Tek. Elektro, Vol. 7, No. 1, Pp. 160-165, 2018

[15] A.S. Tahur, 2019. Rancang Bangun Antar Muka PEngendali 3 Fasa Gelombang Penuh Dengan Personal Computer. Tugas Akhir, Padang:Unp

[16] Priatmoko, Andi. Harahap, Erwin. 2017. "Implementasi Algoritma Des Menggunakan
Matlab". Jurnal Matematika 16(1)

[17] Safaruddin, M. 2015. Pengenalan Matlab dan Simulink. Program Studi Teknik Mesin Sekolah Tinggi Teknologi Mandala.

\section{Biodata Penulis}

Tri Yogi Putra, lahir di Padang, 15 Juni 1996. Menyelesaikan Sarjana Terapan di bidang Teknik Elektro Industri pada Jurusan Teknik Elektro FT UNP.

Muldi Yuhendri, dilahirkan di Agam pada tanggal 13 Desember 1981. Menyelesaikan program Sarjana di jurusan teknik elektro Universitas Negeri Padang pada tahun 2005 dan Program S2 di ITS Surabaya pada tahun 2009 serta S3 Ilmu Teknik Elektro pada tahun 2017 di kampus yang sama. Bekerja sebagai staf pengajar di jurusan teknik elektro Universitas Negeri Padang sejak tahun 2006 sampai sekarang, 